\title{
Seed Dispersal of Threatened Tree Species by a Critically Endangered Primate in a Brazilian Hotspot
}

\author{
Gustavo Rodrigues Canale ${ }^{\mathrm{a}-\mathrm{c}}$ Priscila Suscke ${ }^{\mathrm{d}, \mathrm{e}}$ \\ Larissa Rocha-Santos ${ }^{f}$ Christine Steiner São Bernardo ${ }^{c, g}$ \\ Maria Cecília Martins Kierulff ${ }^{\text {h }}$ David John Chivers ${ }^{\text {a }}$ \\ a Wildlife Research Group, Anatomy School, University of Cambridge, Cambridge, UK; \\ ${ }^{b}$ NEBAM/ICNHS/CUS, Universidade Federal de Mato Grosso, Sinop, 'Campus Cáceres/ \\ Graduate Programme of Environmental Science (PPGCA/UNEMAT), Universidade do Estado \\ de Mato Grosso, Cáceres, ' Graduate Programme of Experimental Psychology (PPGPE/ \\ USP), Universidade de São Paulo, São Paulo, ${ }^{e}$ Graduate Programme of Zoology (PPGZ/ \\ UESC) and ${ }^{f}$ Graduate Programme of Ecology and Biodiversity Conservation (PPGECB/ \\ UESC), Universidade Estadual de Santa Cruz, Ilhéus, ${ }^{9}$ Campus Jequié/Graduate Programme \\ of Genetics, Biodiversity and Conservation (PPGGBC/UESB), Universidade Estadual do \\ Sudoeste da Bahia, Jequié, and h Instituto Pri-Matas, Belo Horizonte, Brazil
}

\author{
Key Words \\ Feeding ecology $\cdot$ Frugivory $\cdot$ Rain forest $\cdot$ Seed deposition
}

\begin{abstract}
In the northern Atlantic Forest, hunting and habitat loss have eliminated most large mammals that disperse zoochoric fruits. Due to the decrease in populations of large seed dispersers, yellow-breasted capuchins (Sapajus xanthosternos) are currently one of the largest arboreal fruit-eating mammals in the region. During 26 months, we followed 14-25 capuchins aiming to (1) present data on their dietary ecology, (2) verify the conservation status of plants in the diet, and (3) determine distance and habitat of seed deposition based on gut retention time. Capuchins showed a preference for feeding in old secondary forests in spite of the greater availability of primary forests. They fed on 109 species of fruits ( $42.7 \%$ of feeding frequency) and swallowed 85 species of seeds (mean width: $0.73 \pm 0.57 \mathrm{~cm}$; mean length: $1.17 \pm 0.83 \mathrm{~cm}$ ). Capuchins consumed mostly oil palm and manilkara fruits. We observed long distances of seed deposition (median 300 $360 \mathrm{~m}$ ); $36.8-41.7 \%$ of these events occurred in a distinct habitat, and seeds of 12 latestage trees swallowed in the primary forest were deposited in old secondary forests. $S$. xanthosternos has an important role in the first phase of seed dispersal (seed removal from the parent tree and seed deposition), particularly for 23 endemic and 3 endangered plants.

๑) 2016 S. Karger AG, Basel
\end{abstract}

\begin{tabular}{ll}
\hline KARGER & $\odot$ 2016 S. Karger AG, Basel \\
E-Mail karger@karger.com & 0015-5713/16/0873-0123\$39.50/0 \\
www.karger.com/fpr &
\end{tabular}

Gustavo Rodrigues Canale

Universidade Federal de Mato Grosso

NEBAM/ICNHS/CUS

Sinop, Mato Grosso (Brazil)

E-Mail g.canale@cantab.net 


\section{Introduction}

Primates disperse seeds from a wide range of tropical tree species [Estrada and Coates-Estrada, 1984; Lapenta et al., 2008; Catenacci et al., 2009; Valenta and Fedigan, 2010]. The various mid-sized and large-bodied species, including Sapajus [Zhang and Wang, 1995; Wehncke et al., 2003; Izar, 2008; Valenta and Fedigan, 2010], Alouatta [Estrada and Coates-Estrada, 1984], Ateles [Zhang and Wang, 1995], and Brachyteles [Martins, 2006; Izar, 2008; Bueno et al., 2013], each feed on fruits of different seed sizes. Thus, seed rain is contingent upon the different seed dispersal capabilities of primates with distinct behaviours and physical characteristics [Wehncke et al., 2003; Moura and McConkey, 2007; Izar, 2008]. This particularly holds true in severely fragmented landscapes, where heavy hunting pressures have reduced the populations of most large-bodied frugivores. The ecological role of the extinct large seed dispersers may not be fully replaced by extant species, as frugivores may play complementary roles in seed dispersal [Chapman and Russo, 2007; Bueno et al., 2013].

Most tropical heavy-wooded trees are threatened not only by forest suppression and the selective logging of economically valuable tree species, but also due to the local extinction of large-bodied seed dispersers [da Silva and Tabarelli, 2000; Jordano, 2000; Tabarelli and Peres, 2002; Chazdon et al., 2003; Guimarães et al., 2008; Peres et al., 2016]. We expect the same trend of tree population decline in the Brazilian Atlantic Forest, considering that up to $90 \%$ of woody species in this biome are endozoochoric [Almeida-Neto et al., 2008; Peres et al., 2016]. The northern Atlantic Forest is also dominated by vertebrate-dispersed tree species, and the reduction of large seeds in the seed rain is associated with the population decline of their seed dispersers [Costa et al., 2012]. This region, particularly the forests in the Brazilian state of Bahia, has extreme biological value for its high plant species richness [Amorim et al., 2008] and endemism [Thomas et al., 1998]. Nonetheless, long-distance dispersers of large seeds, i.e. tapirs, white-lipped peccaries and large-bodied monkeys [Fragoso et al., 2003; Peres et al., 2016], have long been wiped out by poachers in this highly fragmented landscape [Canale et al., 2012]. Thus, large seeds would be dispersed by mid-sized mammals (e.g. capuchin monkeys and kinkajous) and secondary dispersers (e.g. scatter-hoarding rodents), which are more resilient to forest loss than larger mammals [Michalski and Peres, 2007; Canale et al., 2012]. The recruitment of large-seeded trees would depend on quantity of seeds, dispersal distance and environmental quality of seed deposition place generated by these extant seed dispersers. Therefore, due to the severe population depletion of large-bodied seed dispersers, the role of mid-sized mammals (e.g. capuchin monkeys) has become ever more important in order to maintain the dynamics of forest regeneration.

Capuchins (Cebus and Sapajus spp.) are non-restricted frugivores as they eat fruits, seeds, nectar, and small animals [Eisenberg, 1989; Janson and Boinski, 1992; Chivers, 1998]. The foraging and feeding behaviour of capuchins are shown to contribute to the increase in seed survival probability [Zhang and Wang, 1995; Wehncke et al., 2003; Wehncke and Domínguez, 2007; Valenta and Fedigan, 2010]. Short feeding bouts, low number of seeds in faecal droppings, and long travel distances by capuchins are important traits affecting the survival and germination of seeds they swallow [Zhang and Wang, 1995; Wehncke et al., 2003; Valenta and Fedigan, 2010]. As seeds swallowed by capuchins are deposited far from the parent tree and are viable 
after gut passage [Wehncke et al., 2003], seed predation and competition for establishment sites are reduced, and the odds of colonising areas with favourable conditions are increased [Howe and Smallwood, 1982; Nathan and Muller-Landau, 2000; Wehncke et al., 2003; Valenta and Fedigan, 2010].

The frequency distribution of distances travelled by seeds can be obtained if the start and end points of dispersed seeds are known [Nathan and Muller-Landau, 2000]. This is the case for primates, where feeding and defaecating events can be recorded by following study groups [Valenta and Fedigan, 2010]. Studies on foraging activity, dietary preferences, habitat use, daily movements and home range of primates provide information on spatial patterns of seed deposition and the consequences for forest regeneration [Wehncke et al., 2003; Catenacci et al., 2009].

To understand the role of yellow-breasted capuchins as seed disperser in a context where all large frugivores have become extinct, we conducted a study of feeding and foraging activity of Sapajus xanthosternos in a protected forest of Bahia to (1) present data on the dietary ecology of S. xanthosternos, (2) verify the conservation status of plants in the diet of S. xanthosternos and (3) determine distance and habitat of seed deposition by $S$. xanthosternos.

\section{Methods}

Study Area

Una Biological Reserve encompasses one of the largest forest fragments of the northern Atlantic Forest, totalling 18,500 ha. It lies in southern Bahia, Brazil $\left(15^{\circ} 06^{\prime} 12^{\prime \prime} \mathrm{S}, 39^{\circ} 02^{\prime} 12^{\prime \prime} \mathrm{W}\right)$, and its vegetation is composed of mature and regenerating forests (young secondary forests, i.e. $<20$ years since a total clear cut with predominant pioneer trees, and old secondary forests, i.e. $>20$ years since a total clear cut presenting a mixture of pioneers and late-stage trees) [Faria et al., 2009]. The habitat is broadly characterised as lowland moist tropical forest [Mori et al., 1983]. Temperature averages $24-25^{\circ} \mathrm{C}$ annually, and rainfall is approximately $2,000 \mathrm{~mm}$ /year with no evident seasonality [Mori et al., 1983].

In Una, important dispersers of large seeds have been extinct for more than a decade, namely tapirs (Tapirus terrestris), howler monkeys (Alouatta guariba), woolly spider monkeys (Brachyteles hypoxanthus), and white-lipped peccaries (Tayassu pecari) [Canale et al., 2012]. The species observed in Una are typically secondary seed dispersers, namely agoutis (Dasyprocta azarae), crab-eating foxes (Cerdocyon thous), and collared peccaries (Pecari tajacu) [Beckman and Muller-Landau, 2007; Canale et al., 2012]. Extant primary seed dispersers include the yellowbreasted capuchin monkeys (S. xanthosternos), kinkajous (Potos flavus), and large game birds [Beckman and Muller-Landau, 2007; Canale et al., 2012].

Study Group

The yellow-breasted capuchin monkeys are critically endangered [Kierulff et al., 2015], and the total population is estimated to be between 3,500 and 5,000 individuals, scattered in small and isolated populations in the Atlantic Forest, Cerrado and Caatinga [Lernould et al., 2012]. We monitored a radio-tagged group of S. xanthosternos from September 2006 to December 2008. In September 2006, the group was composed of 25 individuals: 3 adult males, 7 adult females, 6 subadult males, 2 subadult females, 4 juvenile females and 3 infants. In September 2007, the group split into 2 subgroups. The subgroup followed comprised 14 individuals: 2 adult males, 3 adult females, 2 subadult males, 2 subadult females, 2 juvenile males, 2 juvenile females and 1 infant. The estimated home range by minimum convex polygon was 1,030 ha before group fission and 969 ha after group fission [Canale, 2010; Canale et al., 2013]. The habitat within these home ranges is mainly formed by primary forests $(57.6 \%)$, followed by young secondary forests $(28.6 \%)$, while the least available habitat was swamp (1.6\%; table 1$)$.

Diet and Seed Dispersal by an Endangered Primate
Folia Primatol 2016;87:123-140 DOI: $10.1159 / 000447712$

125 
Table 1. Percentages of habitat availability, habitat use and feeding records, and richness of fruiting trees in the diet of a group of yellow-breasted capuchin monkeys in Una Biological Reserve from September 2006 to December 2008

\begin{tabular}{lcccl}
\hline Habitat type & $\begin{array}{l}\text { Habitat } \\
\text { availability, \% }\end{array}$ & $\begin{array}{l}\text { Habitat } \\
\text { use, \% }\end{array}$ & $\begin{array}{l}\text { Feeding } \\
\text { records, \% }\end{array}$ & $\begin{array}{l}\text { Richness of fruiting } \\
\text { trees in diet }\end{array}$ \\
\hline Primary forest & 57.6 & 8.2 & 8.0 & 21 \\
Old secondary forest & 6.9 & 46.2 & 28.4 & 61 \\
Young secondary forest & 28.6 & 36.4 & 57.5 & 47 \\
Swamp & 1.6 & 4.3 & 2.7 & 15 \\
Cabruca & 5.3 & 4.9 & 3.4 & 11 \\
\hline
\end{tabular}

\section{Behavioural Data Collection}

Annually, we captured individuals to fit new radio collars as batteries last about 1.5 years. We used a 4-element metal antenna and a VHS receiver (Telonics, model TR-4) to locate the animals with radio collars (Advanced Telemetry Systems Inc., model M1940, 42-60 g). The number of individuals carrying radio collars depended on the number of individuals captured and whether the captured individuals were the required age and body mass to carry a radio collar [details in Kierulff et al., 2005]. Trapped individuals were dye-marked. Nonetheless, most animals in the group were recognised by coat patterns. Sex and age were typically determined during behavioural observations. The capuchins were completely habituated to the observers once observations began.

From September 2006 to August 2007, we collected scan samples at 20-min intervals [Altmann, 1974]. Once the capuchin group had split into 2 subgroups, we were only able to follow the subgroup with the individual carrying the radio collar. The scan interval was reduced to 15 min from September 2007 to December 2008. The variation in scan interval did not interfere with the results, as the analyses were conducted using percentage of behaviour frequency [Martin and Bateson, 2007]. For each individual of the group, the first behaviour observed was recorded during a 5 -min period. To avoid bias towards scan samples with a greater number of individuals being observed, scans were equally weighted by dividing each observation of an individual by the total number of individuals observed in a scan [Kool, 1989].

Groups were followed, typically, from dawn to dusk ( $\mathrm{n}=103$ full days). When we were not able to follow groups for all periods of the day, the period not sampled was completed the following day ( $\mathrm{n}=43$ half-days). A total of 4,657 scans were collected on behaviour. The recorded behaviours were: travel, rest, social, feed and other. 'Travel' involved horizontal and vertical movements. 'Feeding' was recorded when animals were manipulating, chewing or swallowing dietary items [fruit, flowers, tree gum, pith, leaves, bromeliad (foliar base), invertebrates, vertebrates, eggs]. 'Rest' was recorded if animals were lying or simply not moving. 'Social' included affiliative and aggressive interactions. 'Other' included behaviours that represented less than $1 \%$ of the observations (chest-rubbing, drinking water, urine-washing, vigilance).

\section{Fruit Availability}

The survey of productivity of plants was based on trees $\geq 10 \mathrm{~cm}$ in diameter at breast height, as a preliminary survey showed that they are representative of the forest canopy. To estimate abundance of flowers and fruits in Una, we distributed transects $(15 \times 200 \mathrm{~m})$ across the home range of our focal group of capuchins, covering all different habitats (primary forest, old-growth secondary forest, young-growth secondary forest, swamp and cabruca - the last habitat consists of cacao trees planted in the forest shade in an agroforestry system) with the same sampling effort (3 transects/habitat). We randomly placed the transects within each habitat type, at least $1 \mathrm{~km}$ apart. We used the point-centred quarter method [Cottam and Curtis, 1956] and selected points every $15 \mathrm{~m}$ along transects of $200 \mathrm{~m}$, summing to 13 points/transect (39 points and 156 trees per habitat). We marked the 4 nearest trees to a central point on the transect and recorded 
the diameter at breast height and estimated heights. We collected flowers and fruits of the marked trees for identification, and voucher material was deposited at the CEPEC herbarium, Ilhéus, Bahia. From September 2006 to August 2008, we observed monthly the reproductive phenophase of all individuals (flowering, represented by bud and flower, and fruiting, represented by ripe and unripe fruits).

We estimated the monthly fruit and flower availability for each species in each habitat type using the following steps. Firstly, we estimated the intensity of each phenophase (flowering and fruiting) in each individual using the Fournier index [Bencke and Morellato, 2002]. The following intensity values for the Fournier index were: $0=$ reproductive phenophase absent, $1=$ phenophase intensity between 1 and 25\%,2 = between 26 and 50\%, 3 = between 51 and $75 \%$, and $4=$ intensity higher than 75\% [Fournier, 1974]. Secondly, we estimated the monthly intensity index by summing the intensity values for all individuals of the same species in each habitat ( $\Sigma$ Fournier index) and divided the sum by the maximum possible value (i.e. the total number of individuals multiplied by 4). Thirdly, we estimated the activity rate for each species/month by calculating the percentage of sampled trees of the same species that were at the same phenophase. Finally, we estimated the monthly fruit and flower availability for each species in each habitat type by multiplying the monthly intensity index by the activity rate for each species/month. The multiplication intends to distinguish situations in which few individuals produce more fruits and/or flowers, or a great number of individuals produce fewer fruits and/or flowers.

Seed Size and Conservation Status of Plants

Rede SISBIOTA provided seed size based on seeds collected in the Atlantic Forest of Bahia. To classify plants according to their threat level and endemism, we referenced information provided in the IUCN Red List [IUCN, 2016] and the Atlantic Forest Plants - a list of threatened plants of the Atlantic Forest organised with the collaboration of 207 Brazilian and foreign researchers [Stehmann et al., 2009].

\section{Distance and Habitat of Seed Deposition}

According to Schupp et al. [2010], seed dispersal is 'the horizontal movement of the seed by an animal from the place where it was encountered'. In this study, the 'horizontal movement of the seed' is equivalent to the seed deposition distance, based on the gut retention time of the seeds that were observed being swallowed by the yellow-breasted capuchins during the 26 months of fieldwork. We considered gut retention time of $1 \mathrm{~h} 30 \mathrm{~min}$ and $2 \mathrm{~h}$ as this is the range recorded for capuchins in previous studies (1.5 h for Sapajus apella in the wild [Zhang and Wang, 1995]; $94 \pm 43 \mathrm{~min}$ for Cebus capucinus in the wild and $105 \pm 38 \mathrm{~min}$ for S. apella in captivity [Wehncke et al., 2003]; 138 min for C. capucinus in the wild [Valenta and Fedigan, 2010]).

To estimate the distance between the start and end points of swallowed seeds (hereafter seed deposition distance), we used a GPS (error $\leq 5 \mathrm{~m}$ ) to georeference feeding trees whenever capuchins were observed swallowing the seeds (start point) and the location of the centre of the group after $1 \mathrm{~h} 30 \mathrm{~min}$ (and $2 \mathrm{~h}$ ), which corresponds to the place of seed deposition (end point) [similar to Wehncke and Domínguez, 2007]. We counted all the feeding events in a specific habitat type and calculated the percentage of events of seed deposition in the same habitat and in distinct habitat types, based on start and end points.

The probability of seed deposition distance was determined by dividing the number of events of seed deposition for each 100-metre category by the total number of events of seed deposition. We identified the habitat of the feeding tree and the habitat of seed deposition based on a habitat type map of the home range of the capuchins.

Yellow-breasted capuchins moved fast and sometimes travelled $>100 \mathrm{~m}$ apart, similar to other Sapajus [Fragaszy et al., 2004]. Thus, it was difficult to follow the same individual for long periods of time. In addition, only 7 intact faeces could be collected, mainly because defaecation events occurred when they were travelling at heights of $20-25 \mathrm{~m}$. As a result, we could not collect enough faecal samples to have a precise estimate of the number of seeds that passed intact through S. xanthosternos guts.

We are aware of the limitations of using average gut retention time, rather than collected faecal samples, to estimate seed deposition distances [Côrtes and Uriarte, 2013]. However, simi- 
lar to the findings for cercopithecine monkeys [Blaine and Lambert, 2012], minimum and average retention times for related capuchin species did not differ much [Wehncke et al., 2003; Wehncke and Domínguez, 2007]. In a previous study on wild and captive capuchins, no significant differences were detected of seed size effect on gut retention time (range of seed length: $0.33-1.71 \mathrm{~cm}$, seed width: $0.24-0.63 \mathrm{~cm}$ ) [Wencke et al., 2003].

\section{Data Analysis}

The variables were tested for normality using Shapiro-Wilk's test, and residuals were plotted using QQ plot to verify trends. Variables with a skewed distribution were analysed using nonparametric tests. The Spearman rank correlation $\mathrm{R}_{\mathrm{S}}$ was used to test correlations between fruit availability and frequency of feeding on fruits in each habitat type (primary forest, old and young secondary forest, swamp and cabruca). The same procedure was repeated to correlate flower availability and frequency of feeding on flowers in each habitat type. Flower and fruit availabilities were correlated with frequency of feeding on tree gum in each habitat type. Mean values are reported followed by their standard deviation (mean \pm standard deviation). In addition, we performed a $\chi^{2}$ goodness-of-fit test to verify whether feeding records on fruits and habitat use were associated with the habitat availability.

Ethical Statement

This research complied with protocols approved by the ethical and animal care committee of the Brazilian Primate Centre/Chico Mendes Institute and adhered to Brazilian legal requirements.

\section{Results}

\section{Food Availability and Capuchins' Diet}

Over 26 months, S. xanthosternos spent more time feeding on fruits than on any other food item. On average, capuchins fed on fruits in $42.7 \%$ of total feeding frequency ( $\mathrm{SD} \pm 10.3 \%, \mathrm{n}=26$ months), reaching up to $66 \%$ of feeding frequency in November 2006. Invertebrates were the second most frequent item in the diet, averaging $35 \%$ (SD $\pm 6.6 \%, \mathrm{n}=26$ months). During 6 months (December 2006, January 2007, January 2008, April 2008, July 2008, and September 2008), invertebrate consumption was more frequent than that of fruits (fig. 1).

The capuchin group ate fruits of 91 species of trees, 11 species of lianas, 5 palm species, and 2 bamboo species (101 of 109 species identified, see the Appendix). Capuchins fed on up to 27 different fruit species in a month, on average $14.8 \pm 4.9(\mathrm{n}=$ 26 months). Of the 109 plant species of which they ate fruits (Appendix), we observed capuchins swallowing seeds from 85 species $(78 \%)$. Another 11 plant species had their mesocarp removed, and the seeds were dropped/spat out under the parent tree (less than $10 \mathrm{~m}$ radius). Fruits of Elaeis guineensis, Attalea funifera, Eschweilera mattossilvae, Eschweilera ovata, Lecythis lurida, Lecythis pisonis, and Neea verticillata were chewed before being dropped, whilst seeds of Guapira opposita, Caryocar edule, Virola gardneri and Virola officinalis were spat out.

The mean width of seeds swallowed by capuchins was $0.73 \pm 0.57 \mathrm{~cm}$ and seed length was $1.17 \pm 0.83 \mathrm{~cm}$ ( $\mathrm{n}=85$ species). The largest seeds swallowed by subadults and adult capuchins were seeds of Inga edulis (mean seed width: $2.00 \mathrm{~cm}$, mean seed length: $3.20 \mathrm{~cm}$ ) and Tetrastylidium grandifolium (mean seed width: $2.10 \mathrm{~cm}$, mean seed length: $2.20 \mathrm{~cm}$ ). Capuchins also swallowed seeds of two exotic large-seeded tree species, namely cacao (Theobroma cacao; mean seed width: $1.30 \mathrm{~cm}$, mean seed 


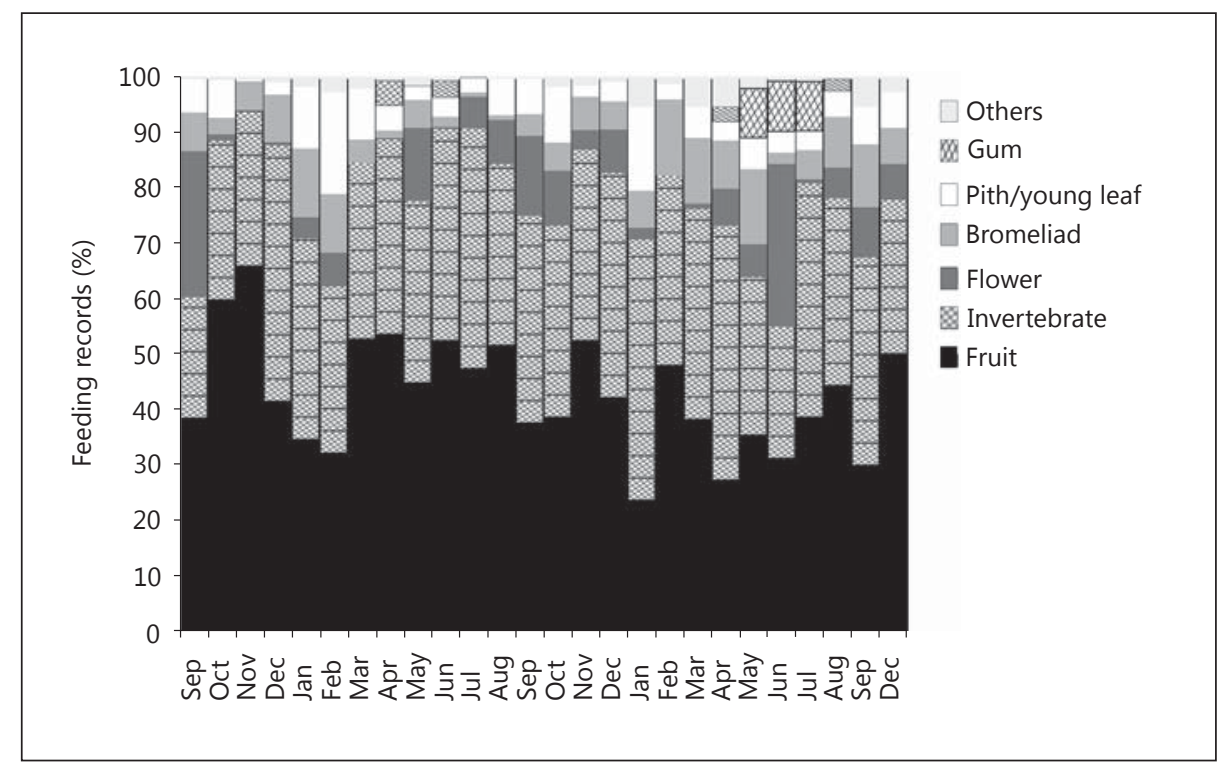

Fig. 1. Percentage of feeding scans on different items for the S. xanthosternos group at Una Biological Reserve from September 2006 to December 2008.

length: $2.30 \mathrm{~cm}$ ) and jackfruit (Artocarpus heterophyllus; mean seed width: $1.60 \mathrm{~cm}$, mean seed length: $2.10 \mathrm{~cm}$; Appendix). Seeds of the endangered Manilkara longifolia (mean seed width: $0.80 \mathrm{~cm}$, mean seed length: $1.39 \mathrm{~cm}$ ) and M. maxima (mean seed width: $0.94 \mathrm{~cm}$, mean seed length: $1.50 \mathrm{~cm}$ ) are also among the largest seeds swallowed (Appendix).

With respect to all records of plant species consumed by capuchins ( $n=447$ feeding records), fruit of the exotic oil palm (Elaeis guineensis) was the commonest identified item in their diet (27.5\% of feeding records). However, only the pulp was eaten, and seeds (mean seed width: $2.45 \mathrm{~cm}$, mean seed length: $2.70 \mathrm{~cm}$ ) were dropped to the forest floor under the parent tree (table 2). Fruits and seeds of the endangered tree M. longifolia were among the most consumed food (4.5\% of feeding records; table 2 ).

The frequency of eating fruits was negatively correlated with the frequency of eating flowers $\left(\mathrm{R}_{\mathrm{S}}=-0.51, \mathrm{p}<0.01, \mathrm{n}=26\right.$ months), while the frequency of eating flowers was negatively correlated with the fruit availability in cabruca $\left(\mathrm{R}_{\mathrm{S}}=-0.52\right.$, $\mathrm{p}<0.01, \mathrm{n}=26$ months). This suggests that nectar was mostly consumed when fruits were less available in this habitat. The frequency of feeding on tree gums of Parkia pendula was negatively correlated with the availability of flowers and fruits in the primary forest $\left(\mathrm{R}_{\mathrm{S}}=-0.49, \mathrm{p}<0.05, \mathrm{n}=26\right.$ months; $\mathrm{R}_{\mathrm{S}}=-0.53, \mathrm{p}<0.01, \mathrm{n}=26$ months, respectively), indicating that tree gum was mostly eaten when flowers and fruits were less available in this habitat. The frequency of feeding on invertebrates was not correlated with the availability of flowers or fruits in any habitat type $(p>0.05)$. The frequency of feeding on fruits in the primary forest was positively correlated with fruit availability in this habitat type $\left(\mathrm{R}_{S}=0.41, \mathrm{p}<0.05, \mathrm{n}=26\right.$ months). No other correlation of fruit availability with frequency of feeding in other habitat types occurred.

Diet and Seed Dispersal by an Endangered Primate
Folia Primatol 2016;87:123-140 DOI: $10.1159 / 000447712$

129 
Table 2. Ten most consumed plant species by S. xanthosternos in Una Biological Reserve from September 2006 to December 2008 ( $\mathrm{n}=447$ feeding records)

\begin{tabular}{lllll}
\hline Family & Species & Item & Feeding, \% & Status \\
\hline Arecaceae & Elaeis guineensis & $\mathrm{Fr}$ & 27.5 & IN \\
Euphorbiaceae & sp. 1 & $\mathrm{Fl} / \mathrm{Fr} / \mathrm{Se}$ & 6.0 & \multirow{2}{*}{ BBSr/EN } \\
Sapotaceae & Manilkara longifolia & $\mathrm{Fl} / \mathrm{Fr} / \mathrm{Se}$ & 4.5 & \\
Sapotaceae & Manilkara salzmanii & $\mathrm{Fl} / \mathrm{Fr} / \mathrm{Se}$ & 3.8 & \\
Moraceae & Ficus sp. & $\mathrm{Fr} / \mathrm{Se}$ & 3.6 & \\
Malphigiaceae & sp. 3 & $\mathrm{Fr} / \mathrm{Se}$ & 2.7 & \\
Menispermaceae & Anomospermum reticulatum & $\mathrm{Fr} / \mathrm{Se}$ & 2.5 & \\
Myrtaceae & sp. 2 & $\mathrm{Fr} / \mathrm{Se}$ & 2.5 & \multirow{2}{*}{ ENA/VU } \\
Arecaceae & Attalea funifera & $\mathrm{Fr}$ & 1.7 & \\
Myristicaceae & Virola gardneri & $\mathrm{Fr}$ & 1.6 & \\
\hline
\end{tabular}

$\mathrm{Fr}=$ Fruit; $\mathrm{Fl}=$ flower; $\mathrm{Se}=$ seed; $\mathrm{BBSr}=$ endemic to Bahia Biogeographical Subregion; ENA = endemic to the northern Atlantic Forest; EN = endangered; VU = vulnerable; IN = human-introduced species.

The observed frequency of feeding on fruits in each habitat type was not proportional to the percentage of habitat available $\left(\chi^{2}=2,561.8, p<0.001\right)$. The higher than expected frequency of feeding on fruits in young and old secondary forests indicates that these habitats are preferred feeding places. Despite the high percentage of primary forest available in the home range of the species, there was a lower percentage of feeding records than expected in this habitat type (table 1). Accordingly, the use of habitat by the group of capuchins was not proportional to the percentage of habitat available $\left(\chi^{2}=11,202.1, \mathrm{p}<0.001\right)$. S. xanthosternos used primary forests less than expected and young and old secondary forest more than expected by the proportion of habitat available. Thus, secondary forests are the most preferred feeding places for capuchins.

Conservation Status of Plants in the Capuchins' Diet

We identified 23 tree species endemic to the Atlantic Forest in the diet of S. xanthosternos (fruits, flowers, seeds, or palm hearts), 5 of which are threatened late-stage trees. From all seed species swallowed ( $\mathrm{n}=85$ species), $21 \%$ are endemic to the Atlantic Forest and $4.7 \%$ restrictively endemic to Bahia Biogeographical Subregion. For tree species only ( $\mathrm{n}=80$ species), $21 \%$ were endemic to the Atlantic Forest, $5 \%$ endemic to Bahia Biogeographical Subregion, and $6.2 \%$ were threatened with extinction ( 3 endangered and 2 vulnerable species).

Three timber species (Manilkara spp.) and 2 human-introduced species, with relevant economic value, had seeds swallowed by S. xanthosternos (cacao T. cacao and jackfruit A. heterophyllus). They fed on fruits without swallowing seeds of 4 other plants of important economic value (A. funifera, C. edule, E. guineensis and L. pisonis). They also fed on flowers of Symphonia globulifera and Euterpe edulis, and the palm heart of the latter. In addition, they ate the palm heart of 3 species of Bactris, including the endemic B. ferruginea (Appendix). 
Table 3. Mean distance of seed deposition (MD, in metres) and percentage of events of seed deposition in a distinct habitat (dep.) after gut retention times of 1.5 and $2 \mathrm{~h}$

\begin{tabular}{|c|c|c|c|c|c|c|c|c|}
\hline \multirow[t]{3}{*}{ Habitat of feeding tree } & \multicolumn{8}{|c|}{ Distinct habitat of seed deposition } \\
\hline & \multicolumn{4}{|l|}{$1.5 \mathrm{~h}$} & \multicolumn{4}{|l|}{$2 \mathrm{~h}$} \\
\hline & dep., $\%$ & $\mathrm{n}$ & $\mathrm{MD}, \mathrm{m}$ & $\mathrm{n}$ & dep., \% & $\mathrm{n}$ & $\mathrm{MD}, \mathrm{m}$ & $\mathrm{n}$ \\
\hline Primary forest & 55.7 & 61 & $294 \pm 192$ & 61 & 55.7 & 61 & $356 \pm 234$ & 61 \\
\hline Old secondary forest & 32.0 & 125 & $291 \pm 192$ & 121 & 40.8 & 125 & $343 \pm 215$ & 121 \\
\hline Young secondary forest & 29.0 & 93 & $377 \pm 209$ & 89 & 30.1 & 93 & $423 \pm 215$ & 88 \\
\hline Swamp & 100.0 & 6 & $375 \pm 98$ & 6 & 100.0 & 6 & $449 \pm 102$ & 6 \\
\hline Cabruca & 27.3 & 22 & $202 \pm 133$ & 20 & 40.9 & 22 & $278 \pm 165$ & 20 \\
\hline Overall & 36.8 & 307 & $313 \pm 198$ & 297 & 41.7 & 307 & $368 \pm 218$ & 296 \\
\hline
\end{tabular}

$\mathrm{n}=$ Sample size

Fig. 2. Probability of seed deposition distance $(\mathrm{n}=215$ events) for a group of $S$. xanthosternos at Una Biological Reserve.

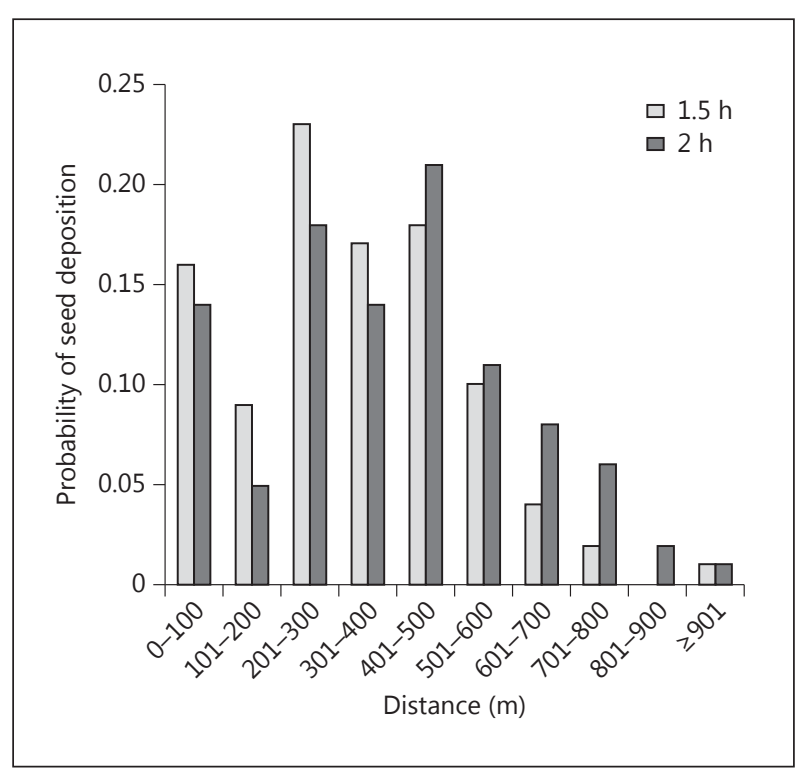

\section{Distance and Habitat of Seed Deposition}

Seed deposition distance varied from 0 to $1,140 \mathrm{~m}$, with the highest probability of seed deposition distance for a seed retention time of $1.5 \mathrm{~h}$ ranging from 201 to $300 \mathrm{~m}(\mathrm{p}=0.23)$ and from 401 to $500 \mathrm{~m}(\mathrm{p}=0.21)$ for a seed retention time of $2 \mathrm{~h}$. Thus, it is most likely that seeds are placed between 201 and $500 \mathrm{~m}$ away from the parent tree (fig. 2). We found a long distance of seed deposition for gut retention of $1.5 \mathrm{~h}$, i.e. $313 \pm 198 \mathrm{~m}$ (median $=300 \mathrm{~m}, \mathrm{n}=297$ ), and an even longer one for gut retention of 2 h, i.e. $368 \pm 218 \mathrm{~m}$ (median $=360 \mathrm{~m}, \mathrm{n}=296$; table 3 ).

Diet and Seed Dispersal by an Endangered Primate
Folia Primatol 2016;87:123-140 DOI: $10.1159 / 000447712$ 
Table 4. Percentage of events of seed deposition coming from distinct habitats (dep.), after gut retention times of 1.5 and $2 \mathrm{~h}$

\begin{tabular}{|c|c|c|c|c|}
\hline \multirow[t]{3}{*}{ Habitat of seed deposition } & \multicolumn{4}{|c|}{ Distinct habitat of feeding tree } \\
\hline & \multicolumn{2}{|l|}{$1.5 \mathrm{~h}$} & \multicolumn{2}{|l|}{$2 \mathrm{~h}$} \\
\hline & dep., \% & $\mathrm{n}$ & dep., $\%$ & $\mathrm{n}$ \\
\hline Primary forest & 27.0 & 37 & 34.1 & 41 \\
\hline Old secondary forest & 38.8 & 139 & 43.9 & 132 \\
\hline Young secondary forest & 35.3 & 102 & 37.5 & 104 \\
\hline Swamp & 100.0 & 11 & 100.0 & 11 \\
\hline Cabruca & 11.1 & 18 & 31.6 & 19 \\
\hline Overall & 36.8 & 307 & 41.7 & 307 \\
\hline
\end{tabular}

$\mathrm{n}=$ Sample size

All seeds swallowed in swamps were potentially deposited in other habitat types. Also, $55.7 \%$ of the feeding events in primary forests resulted in potential seed deposition in a different habitat type. We observed similar results for swamp and primary forests, considering a slower gut passage time $(2 \mathrm{~h})$. The smallest frequency of seed deposition into another habitat $(27.3 \%)$ was recorded for seeds swallowed in cabruca. Ultimately, the percentage of seed deposition events occurring in a distinct habitat type increased according to the length of gut passage time, from 36.8 to $41.7 \%$ (for 1.5 and $2 \mathrm{~h}$, respectively; table 3 ).

We observed that $95 \%$ of the feeding events of fruits in the primary forest, with seed deposition in the old secondary forest, involved 12 species of late-stage trees. Moreover, $50 \%$ of the feeding events on fruits in the primary forest with seed deposition in the young secondary forest involved 2 species of late-stage trees. Only 1 feeding event of fruits in the primary forest with seed deposition in the swamp was observed (Manilkara sp., a late-stage tree) and no seed deposition from fruits eaten in primary forest to cabruca. On the other hand, $68 \%$ of feeding events in the old secondary forests, with seed deposition in the young secondary forests, involved 9 species of pioneer trees. Only 1 feeding event on fruits in the old secondary forest with seed deposition in cabruca was recorded (Manilkara sp.), and only 2 feeding events of fruits in the old secondary forests with seed deposition in swamp (2 late-stage tree species, namely Manilkara salzmanii and Pouteria sp.). We observed that between 38.8 and $43.9 \%$ of seed deposition events to old secondary forests came from a different habitat type (for 1.5 and $2 \mathrm{~h}$ of seed retention time, respectively). For young secondary forests, between 35.3 and $37.5 \%$ of events came from a different habitat type (for 1.5 and $2 \mathrm{~h}$ of seed retention time, respectively; table 4 ).

\section{Discussion}

S. xanthosternos swallowed seeds of 80 tree species (17 endemic and 5 threatened), including large-seeded species, such as the threatened Manilkara spp. and Rauvolfia bahiensis, and the exotics cacao (T. cacao) and jackfruit (A. heterophyllus). Ma- 
nilkara spp. are known to be potentially dispersed by at least 6 primate species, including 2 species of capuchins (S. apella and S. olivaceus) [Ratiarison and Forget, 2011]. Manilkara elata, M. longifolia and M. maxima are late-stage trees that have large and fleshy fruits and occur in well-preserved habitats (e.g. primary forests) and old-growth forests [Lorenzi, 2000]. They are highly valued for their toughness and longevity in the construction industry and are among the most sought after species in the local black market [G. Canale, pers. observation]. The cubic-metre value may reach up to 3 times the Brazilian minimum wage (about $780 \mathrm{USD} / \mathrm{m}^{3}$ ) [Amorim et al., 2011]. The yellowbreasted capuchins rarely fed on fruits in the primary forest despite the high availability of this habitat type within their home range. In fact, they showed a preference for feeding in old secondary forests. However, fruiting peaks of Manilkara spp. increased the frequency of feeding on fruits in the primary forest. They also consumed flowers of Manilkara spp. in the primary and the old secondary forests (flowering peak: May to June), and S. globulifera in the swamp (flowering peak: September to November) when fruits of cacao were not ripe in cabruca. Furthermore, the yellow-breasted capuchin monkeys frequently used the young secondary forest during months of low availability of fruits and flowers in the primary forest to eat tree gums (Parkia pendula). It suggests that $P$. pendula is an important food source during flower and fruit scarcity, as previously reported for S. apella in the Amazon [Peres, 2000].

Studies on Neotropical primates demonstrate their importance to forest regeneration, specifically when dispersing seeds from primary forests to secondary forests [Catenacci et al., 2009; Culot et al., 2010]. Interestingly, fruiting trees from primary forests had one of the highest habitat type turnover in Una, involving seeds of 12 species of late-stage trees swallowed in this habitat and deposited in old secondary forests. Virtually all species of late-stage trees benefit from canopy gaps to reach reproductive maturity [Wenny and Levey, 1998]; thus, colonisation is likely to occur when seeds from pristine environments are deposited in more degraded habitats by seed dispersers, e.g. S. xanthosternos. On the other hand, we must consider postdispersal seed fate variations, which may reduce the effectiveness of the capuchin monkeys as ecosystem engineers [Chapman et al., 2013].

The deposition of seeds in a new habitat does not guarantee the establishment of seedlings [Nathan and Muller-Landau, 2000]. For example, seeds swallowed in the swamp by the yellow-breasted capuchins may not germinate when dropped in dryer habitats due to the unfavourable environmental conditions for seeds of typically humid environments. However, it is commonly acknowledged that the distance of seed dispersal from the parent tree improves recruitment survival [Janzen, 1970; Howe and Smallwood, 1982; Muller-Landau, 2007]. The capuchins also travelled long distances in a short period of time, leading to seed deposition away from the parent tree (median $=300-360 \mathrm{~m}$, for gut retention times of $1.5-2 \mathrm{~h}$ ). This is similar to results found for a group of Sapajus nigritus (median $=320 \mathrm{~m}$ ), yet considerably longer than findings for 2 groups of C. capucinus (median $=195$ and $169 \mathrm{~m}$ ) [Wehncke et al., 2003; Wehncke and Domínguez, 2007]. Yellow-breasted capuchins defaecate in small clumps over a wide area, as do spider monkeys, and not in latrines, as howler monkeys do. This defaecation pattern decreases the density of seeds in each dropping and reduces the attraction of density-dependent predators and/or pathogens [González-Zamora et al., 2012]. Moreover, seeds dropped from an animal's mouth might also have an increased survival rate due to pulp removal and decreased fungal attack on processed seeds [Lambert, 2001; Barnett et al., 2012], despite greater competition under the parent 
tree. This may be the case for the 11 species of which the seeds were spat out or dropped by the yellow-breasted capuchins, thus falling under the parent tree.

Although capuchins can act as important seed dispersers of threatened native plant species, this role may be diminished because of the high consumption of exotic species. In our study region, secondary forests were the most preferred feeding places by $S$. xanthosternos, which are a mixture of abandoned oil palm plantations and a species-rich regenerating forest of native trees. Accordingly, fruits of the exotic oil palm were frequently consumed in the young secondary forests $(51.8 \%$ of feeding on fruits), while seeds of native manilkaras were frequently swallowed in the old secondary forests (31\% of feeding on fruits). The mixture of exotic species and native trees could be used favourably in species management for conservation, as the exotic species supplement the capuchins' food needs [Gosper and Vivian-Smith, 2009; Estrada et al., 2012]. However, the high consumption of oil palm seeds may not provide all the required nutrients, and different food items are needed to balance the capuchins' nutrient intake. Oil palm mesocarp is exceptionally rich in oil (80\% dry mass) [Tranbarger et al., 2008], and, despite its high-energy contents (approx. $33 \mathrm{~kJ} / \mathrm{g}$ ) [Vogel, 2005], it has a low glucose proportion (i.e. only $7 \mathrm{mg} / \mathrm{g}$ of dry weight in comparison to $19-21 \mathrm{mg} / \mathrm{g}$ of sucrose) [Kok et al., 2011]. Therefore, the total replacement of secondary forests by extensive oil palm plantations, as projected by incentive programmes for oil palm growth by the Brazilian Government [Englund et al., 2015], may negatively affect the capuchin populations.

Jackfruit and cacao are other exotic fruits in the in the diet of S. xanthosternos, but are not so frequently consumed during the year as are oil palm fruits. In some months, however, they may reach $20 \%$ (cacao) and 16\% (jackfruit) of the frequency of feeding on fruits. Thus, they may also compete with native trees for their dispersal services. Cacao seeds and jackfruit seeds represent the upper limit size of seeds ingested by Cebus = Sapajus [Wehncke et al., 2003]. Indeed, they were the largest exotic seeds swallowed by the yellow-breasted capuchins and were found intact in the few faecal droppings collected in Una ( $n=7$ faecal samples). Despite the potential use of exotic fruits as supplementary food in the management and conservation of threatened fauna species, the high frequency of feeding on exotic fruits directly reduces the time allocated to feed on native fruits, including threatened trees [Gosper et al., 2005; Canale et al., 2013]. To understand the impact of exotic plants in the dispersal of native seeds by the yellow-breasted capuchins, we recommend studies of yellow-breasted capuchins living in areas with no exotic plants. Furthermore, field experiments on seed germination of native trees, particularly involving seeds of late-stage trees consumed in pristine environments and deposited in more degraded areas, are relevant to understand the role of capuchins in the regeneration of forests.

Our results highlight the importance of the yellow-breasted capuchins' ecological function for forest regeneration dynamics. The most consumed fruits by S. xanthosternos have larger seeds than the average of seeds swallowed, indicating that these monkeys feed on large-seeded fruits at a high frequency. In addition, yellow-breasted capuchins spend much of their time foraging across different habitat types, similar to other Cebus and Sapajus [Zhang, 1995; Siemers, 2000]. They visited 5 distinct habitat types feeding on fruits of exotic and threatened native species, and travelled long distances in a short period of time. As a result, seeds were frequently deposited away from the parent tree and in a different habitat from the one in which they were originally consumed. Despite acting as supplementary food for capuchins, the high con- 
sumption of exotic plants (e.g. cacao, jackfruit and oil palm) in remnant forests compete with threatened and endemic large-seeded tree species for the important dispersal services of one of their last seed dispersers, the yellow-breasted capuchins.

\section{Appendix: Plant species of which the reproductive parts were eaten by C. xanthosternos in Una Biological Reserve from September 2006 to Decem- ber 2008}

\begin{tabular}{|c|c|c|c|c|c|c|c|c|}
\hline Family & Species & Item & RS & AFP & Endemism & IUCN & $\begin{array}{l}\text { Seed } \\
\text { width, } \\
\mathrm{cm}\end{array}$ & $\begin{array}{l}\text { Seed } \\
\text { length, } \\
\mathrm{cm}\end{array}$ \\
\hline Anacardiaceae & Tapirira guianensis & Fruit, seed & Intol. & & & & 0.68 & 1.08 \\
\hline \multirow[t]{2}{*}{ Annonaceae } & Annona glabra & Fruit, seed & Tol. & & & & 1.21 & 2.07 \\
\hline & Annona sp. & Fruit, seed & & & & & - & - \\
\hline Apocynaceae & Rauvolfia bahiensis & Fruit, seed & Intol. & & $\mathrm{BBSr}$ & VU & 0.82 & 1.39 \\
\hline \multirow[t]{6}{*}{ Arecaceae } & Attalea funifera & Fruit & Intol. & VU & ENA & & 4.00 & 7.80 \\
\hline & Bactris ferruginea & Fruit, seed, palm & Intol. & & EAF & & 1.68 & 1.84 \\
\hline & Bactris setosa & Fruit, seed, palm & Intol. & & & & 1.71 & 1.48 \\
\hline & Bactris sp. & Fruit, seed, palm & & & & & - & - \\
\hline & Elaeis guineensis & Fruit & Intol. & & Exotic & & & \\
\hline & Euterpe edulis & Flower, palm & Tol. & EN & & & 1.16 & 1.03 \\
\hline Bonnetiaceae & Bonnetia sp. & Fruit, seed & & & & & - & - \\
\hline \multirow[t]{2}{*}{ Boraginaceae } & Cordia anabaptista & Fruit, seed & Intol. & & & & 0.71 & 1.32 \\
\hline & Tournefortia sp. & Fruit, seed & & & & & - & - \\
\hline Burseraceae & Protium heptaphyllum & Fruit, seed & Tol. & & & & 0.75 & 1.39 \\
\hline Caryocaraceae & Caryocar sp. & Fruit & Tol. & & & & - & - \\
\hline Celastraceae & Maytenus sp. & Fruit, seed & & & & & - & - \\
\hline \multirow[t]{4}{*}{ Chrysobalanaceae } & Couepia monteclarensis & Fruit, seed & Tol. & & EAF & & - & - \\
\hline & Couepia sp. & Fruit, seed & Tol. & & & & - & - \\
\hline & Licania discolor & Fruit, seed & Tol. & & & & 0.30 & 1.50 \\
\hline & Licania sp. & Fruit, seed & Tol. & & & & - & - \\
\hline \multirow[t]{2}{*}{ Clusiaceae } & Symphonia globulifera & Flower & Intol. & & & & 2.10 & 2.40 \\
\hline & Tovomita brasiliensis & Fruit, seed & Tol. & & & & 0.60 & 1.60 \\
\hline \multirow[t]{2}{*}{ Ebenaceae } & Diospyros inconstans & Fruit, seed & Tol. & & & & 0.80 & 1.40 \\
\hline & Diospyros sp. & Fruit, seed & & & & & - & - \\
\hline \multirow[t]{3}{*}{ Euphorbiaceae } & Dalechampia ilheotica & Fruit, seed & Tol. & & ENA & & - & - \\
\hline & Euphorbiaceae sp. & Flower, fruit, seed & Tol. & & & & - & - \\
\hline & Sebastiania gaudichaudii & Fruit, seed & & & $\mathrm{AF}$ & & - & - \\
\hline \multirow[t]{7}{*}{ Fabaceae } & Inga capitata & Fruit, seed & Intol. & & & & 1.10 & 1.40 \\
\hline & Inga edulis & Fruit, seed & Intol. & & & & 1.00 & 3.20 \\
\hline & Inga marginata & Fruit, seed & Intol. & & & & 0.50 & 1.00 \\
\hline & Inga thibaudiana & Fruit, seed & Intol. & & & & 1.10 & 1.70 \\
\hline & Pterocarpus rohrii & Flower & Intol. & & & & 1.10 & 1.70 \\
\hline & Senna multijuga & Flower & Intol. & & & & 0.30 & 0.80 \\
\hline & Fabaceae sp. & Fruit, seed & Intol. & & & & - & - \\
\hline
\end{tabular}

Diet and Seed Dispersal by an Endangered Primate
Folia Primatol 2016;87:123-140 DOI: $10.1159 / 000447712$ 


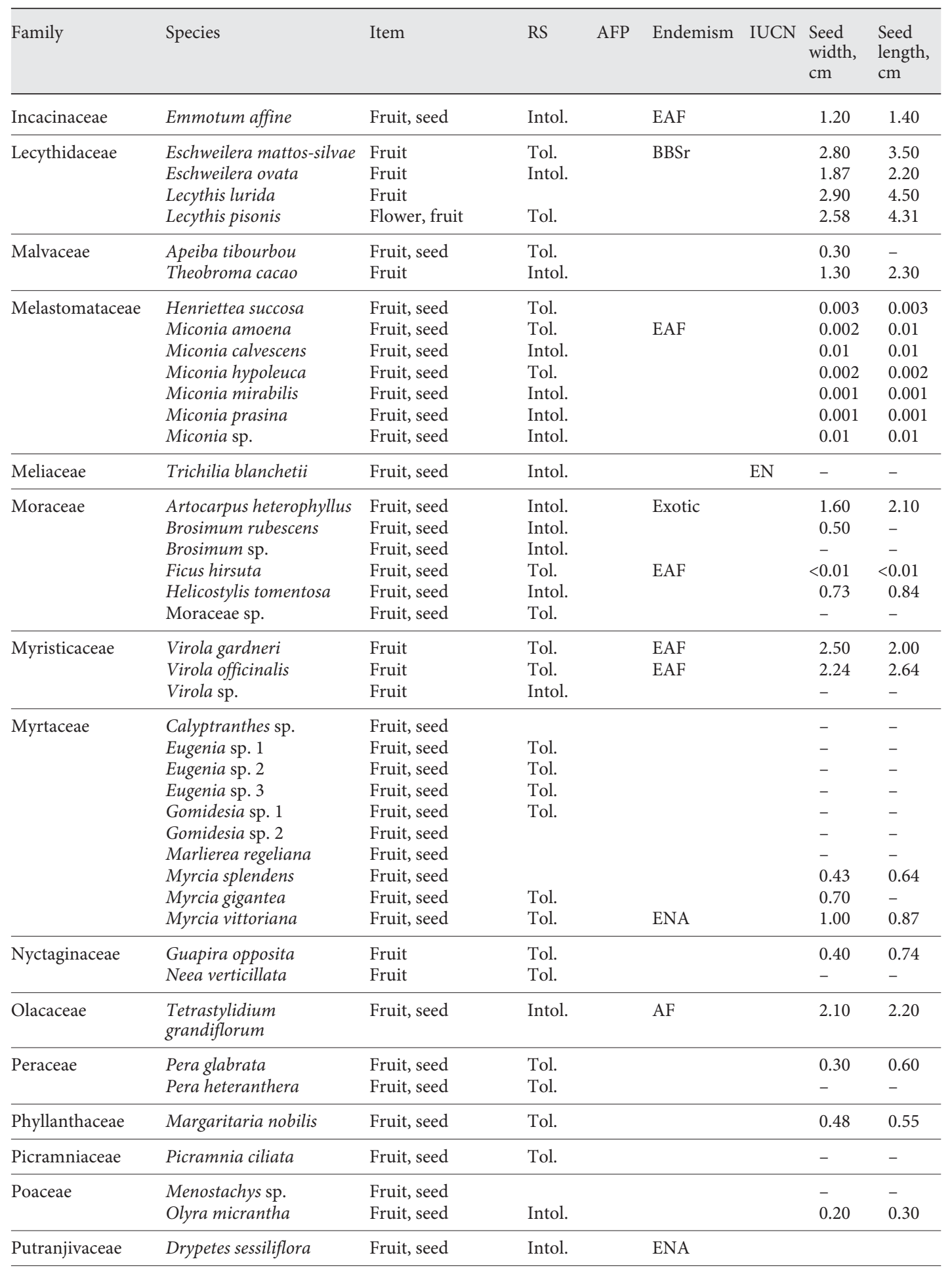




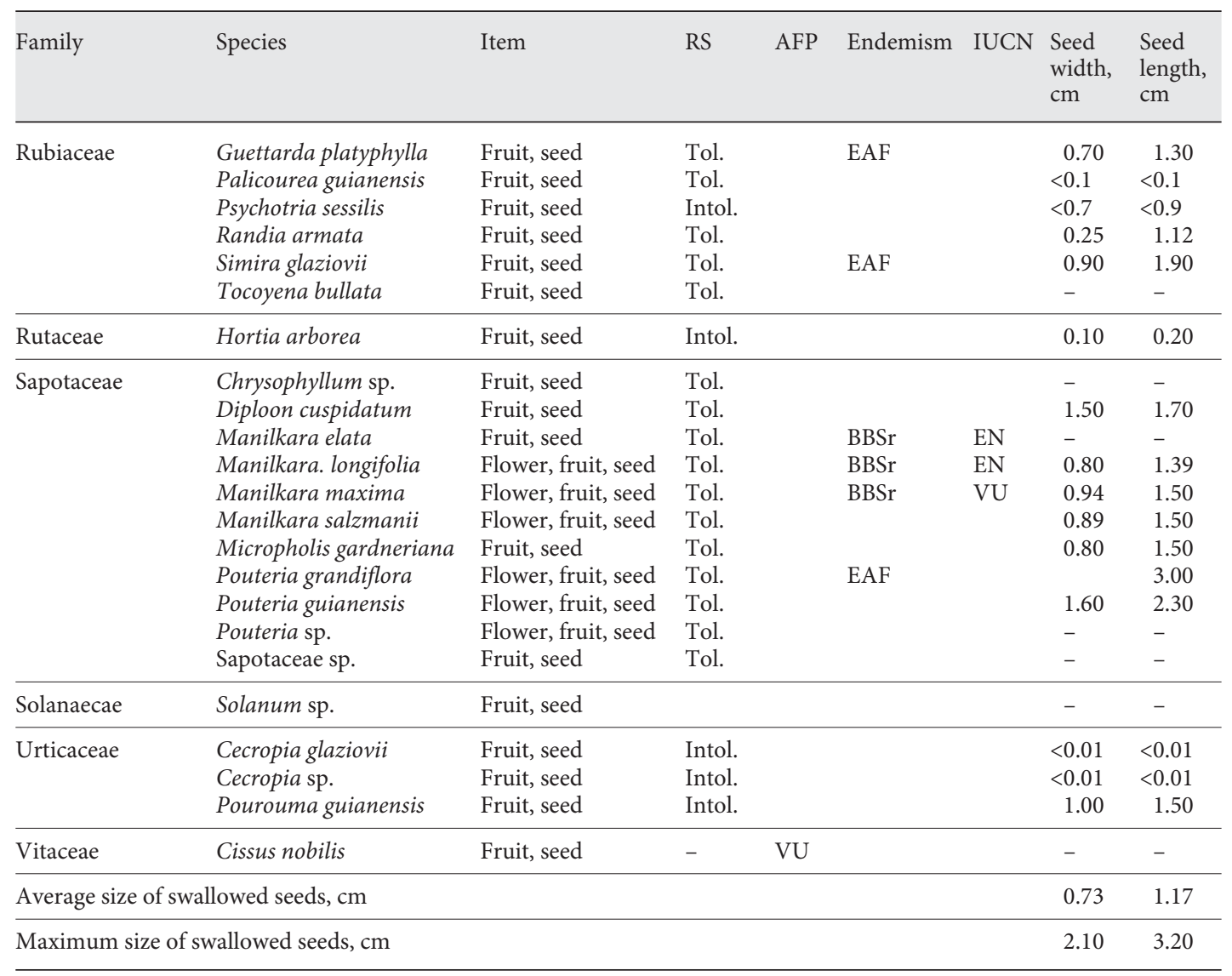

AFP = Conservation status and endemism followed IUCN Red List [IUCN, 2016] and Brazilian Red List; AF = Atlantic Forest; $\mathrm{EAF}=$ endemic to the Atlantic Forest; ENA = endemic to the northern Atlantic Forest; $\mathrm{BBSr}=$ endemic to Bahia Biogeographical Subregion; EN = endangered; VU = vulnerable; RS = regeneration strategy; intol. = shade-intolerant; tol. = shade-tolerant.

\section{Acknowledgements}

We acknowledge CAPES for the doctorate degree scholarship for G.R.C. and postdoctoral scholarships for C.S.S.B. and M.C.M.K. We thank the editor and anonymous reviewers for their valuable comments. We appreciate Giovanna Canale Olinto for proofreading the text. We are grateful to Jamile A. Bonfim and Michaele S. Pessoa for information on seed size collected during the research of 'Rede SISBIOTA' (funded by CNPq, proc. 563216/2010-7), Universal/CNPq 481400/2011-7, PROPP/UESC (00220.1100.02), and FAPESB (JCB0049/2013).

\section{References}

Almeida-Neto M, Campassi F, Galetti M, Jordano P, Oliveira-Filho A (2008). Vertebrate dispersal syndromes along the Atlantic forest: broad-scale patterns and macroecological correlates. Global Ecology and Biogeography 17: 503-513.

Altmann J (1974). Observational study of behavior - sampling methods. Behaviour 49: 227-267.

Diet and Seed Dispersal by an Endangered Primate
Folia Primatol 2016;87:123-140 DOI: $10.1159 / 000447712$ 
Amorim AM, Thomas WW, Carvalho AMV, Jardim JG (2008). Floristic of the Una Biological Reserve, Bahia, Brazil. In The Atlantic Coastal Forests of Northeastern Brazil (Thomas WW, ed.), pp 67-146. New York, Memoirs of the New York Botanical Garden.

Amorim JS, Neto APS, Silva GC, Ferreira JS (2011). Characterization of business from the origin of wood raw material to the generation of waste in Itapetinga - BA. Enciclopédia Biosfera 7: 1-8.

Barnett AA, Boyle SA, Pinto LP, Lourenço WC, Almeida T, Sousa-Silva W, Spironello WR (2012). Primary seed dispersal by three Neotropical seed-predating primates (Cacajao melanocephalus ouakary, Chiropotes chiropotes and Chiropotes albinasus). Journal of Tropical Ecology 28: 543-555.

Beckman NG, Muller-Landau HC (2007). Differential effects of hunting on pre-dispersal seed predation and primary and secondary seed removal of two Neotropical tree species. Biotropica 39: 328-339.

Bencke CS, Morellato LPC (2002). Comparação de doismétodos de avaliação da fenologia de plantas, sua interpretação e representação. Revista Brasileira de Botânica 25: 269-275.

Blaine KP, Lambert JE (2012). Digestive retention times for Allen's swamp monkey and L'Hoest's monkey: data with implications for the evolution of cercopithecine digestive strategy. Integrative Zoology 7 : $183-191$.

Bueno RS, Guevara R, Ribeiro MC, Culot L, Bufalo FS, Galetti M (2013). Functional redundancy and complementarities of seed dispersal by the last Neotropical megafrugivores. PLoS One 8: e56252.

Canale GR (2010). Ecology and Behaviour of the Yellow-Breasted Capuchin Monkey Cebus xanthosternos in the Northern Atlantic Forest. $\mathrm{PhD}$ thesis, University of Cambridge.

Canale GR, Guidorizzi CE, Kierulff MCM, Gatto CAR (2012). Pervasive defaunation of forest remnants in a tropical biodiversity hotspot. PLoS One 7: 41-71.

Canale GR, Kierulff MCM, Chivers DJ (2013). A critically endangered capuchin monkey Sapajus xanthosternos living in a highly fragmented hotspot. In Primates in Fragments: Complexity and Resilience (Marsh LK, Chapman CA, eds.), pp 299-311. New York, Springer.

Catenacci LS, De Vleeschouwer KM, Nogueira SLG (2009). Seed dispersal by golden-headed lion tamarins Leontopithecus chrysomelas in southern Bahian Atlantic forest, Brazil. Biotropica 41: 744-750.

Chapman CA, Russo SE (2007). Primate seed dispersal. In Primates in Perspective (Campbell CJ, Fuentes A, McKinnon KC, Panger M, Bearder S, eds.), pp 510-525. New York, Oxford University Press.

Chapman CA, Bonnell TR, Gogarten JF, Lambert JE, Omeja PA (2013). Are primates ecosystem engineers? International Journal of Primatology 34: 1-14.

Chazdon RL, Careaga S, Webb C, Vargas O (2003). Community and phylogenetic structure of reproductive traits of woody species in wet tropical forests. Ecological Monographs 73: 331-348.

Chivers DJ (1998). Measuring food intake in wild animals: primates. Proceedings of the Nutrition Society 57: 321-332.

Côrtes MC, Uriarte M (2013). Integrating frugivory and animal movement: a review of the evidence and implications for scaling seed dispersal. Biological Reviews 88: 255-272.

Costa JB, Melo FP, Santos BA, Tabarelli M (2012). Reduced availability of large seeds constrains Atlantic forest regeneration. Acta Oecologica 39: 61-66.

Cottam G, Curtis JT (1956). The use of distance measures in phytosociological sampling. Ecology 37: 451-460.

Culot L, Muñoz Lazo FJJ, Huynen MC, Poncin P, Heymann EW (2010). Seasonal variation in seed dispersal by tamarins alters seed rain in a secondary rainforest. International Journal of Primatology 31: 553-569.

Da Silva JMC, Tabarelli M (2000). Tree species impoverishment and the future flora of the Atlantic forest of northeast Brazil. Nature 404: 72-74.

Eisenberg JF (1989). Mammals of the Neotropics: The Northern Neotropics. Chicago, University of Chicago Press.

Englund O, Berndes G, Persson UM, Sparovek G (2015). Oil palm for biodiesel in Brazil - risks and opportunities. Environmental Research Letters 10: 044002.

Estrada A, Coates-Estrada R (1984). Fruit eating and seed dispersal by howling monkeys (Alouatta palliata) in the tropical rain forest of Los-Tuxtlas, Mexico. American Journal of Primatology 6: 77-91.

Estrada A, Raboy BE, Oliveira LC (2012). Agroecosystems and primate conservation in the tropics: a review. American Journal of Primatology 74: 696-711.

Faria D, Mariano-Neto E, Martini AMZ, Ortiz JV, Montingelli R, Rosso S, Baumgarten J (2009). Forest structure in a mosaic of rainforest sites: the effect of fragmentation and recovery after clear cut. Forest Ecology and Management 257: 2226-2234.

Fournier LA (1974). Un método cuantitativo para la medición decaracterísticas fenológicas en árboles. Turrialba 24: 422-423.

Fragaszy D, Izar P, Visalberghi E, Ottoni EB, De Oliveira MG (2004). Wild capuchin monkeys (Cebus libidinosus) use anvils and stone pounding tools. American Journal of Primatology 64: 359-366.

Fragoso JM, Silvius KM, Correa JA (2003). Long-distance seed dispersal by tapirs increases seed survival and aggregates tropical trees. Ecology 84: 1998-2006. 
González-Zamora A, Arroyo-Rodríguez V, Oyama K, Sork V, Chapman CA, Stoner KE (2012). Sleeping sites and latrines of spider monkeys in continuous and fragmented rainforests: implications for seed dispersal and forest regeneration. PLoS One 7: e46852.

Gosper CR, Vivian-Smith G (2009). Approaches to selecting native plant replacements for fleshy-fruited invasive species. Restoration Ecology 17: 196-204.

Gosper CR, Stansbury CD, Vivian-Smith G (2005). Seed dispersal of fleshy-fruited invasive plants by birds: contributing factors and management options. Diversity and Distributions 11: 549-558.

Howe HF, Smallwood J (1982). Ecology of seed dispersal. Annual Review of Ecology and Systematics 13: 201-228 IUCN (2016). The IUCN Red List of Threatened Species. Version 2016-1. http://www.iucnredlist.org. Downloaded on 12 August 2016.

Guimarães PR Jr, Galetti M, Jordano P (2008). Seed dispersal anachronisms: rethinking the fruits extinct megafauna ate. PLoS One 3: e1745.

Izar P (2008). Dispersão de sementes por Cebus nigritus e Brachyteles arachnoides em área de Mata Atlântica, Parque Estadual Intervales, SP. In A Primatologia no Brasil (Ferrari SF, Rímoli J, eds.), vol 9, pp 8-24. Aracajú, Sociedade Brasileira de Primatologia, Biologia Geral e Experimental.

Janson CH, Boinski S (1992). Morphological and behavioral adaptations for foraging in generalist primates - the case of the cebines. American Journal of Physical Anthropology 88: 483-498.

Janzen DH (1970). Herbivores and number of tree species in tropical forests. American Naturalist 104: 501.

Jordano P (2000). Fruits and frugivory. In Seeds: The Ecology of Regeneration in Plant Communities (Fenner M, ed.), 2nd ed., pp 125-166. Wallingford, CABI Publishing.

Kierulff MCM, Canale G, Suscke P (2005). Monitoring the yellow-breasted capuchin monkey (Cebus xanthosternos) with radiotelemetry: choosing the best radio-collar. Neotropical Primates 13: 32-33.

Kierulff MCM, Mendes SL, Rylands AB (2015). Sapajus xanthosternos. The IUCN Red List of Threatened Species 2015: e.T4074A70615251. http://dx.doi.org/10.2305/IUCN.UK.2015-1.RLTS. T4074A70615251.en

Kok S, Ong-Abdullah M, Ee GC, Namasivayam P (2011). Comparison of nutrient composition in kernel of tenera and clonal materials of oil palm (Elaeis guineensis Jacq.). Food Chemistry 129: 1343-1347.

Kool KM (1989). Behavioural Ecology of the Silver Leaf Monkey, Trachypithecus auratus sondaicus, in the Pangandaran Nature Reserve, West Java, Indonesia. PhD thesis, University of New South Wales, Sydney.

Lambert JE (2001). Red-tailed guenons (Cercopithecus ascanius) and Strychnos mitis: evidence for plant benefits beyond seed dispersal. International Journal of Primatology 22: 189-201.

Lapenta MJ, Procópio-de-Oliveira P, Kierulff MCM, Motta-Junior JC (2008). Frugivory and seed dispersal of golden lion tamarin (Leontopithecus rosalia, Linnaeus, 1766) in a forest fragment in the Atlantic Forest, Brazil. Brazilian Journal of Biology 68: 241-249.

Lernould JM, Kierulff MCM, Canale G (2012). Yellow-breasted capuchin Cebus xanthosternos: support by zoos for its conservation - a success story. International Zoo Yearbook 46: 71-79.

Lorenzi H (2000). Brazilian Trees, vol 1 and 2. Nova Odessa, Instituto Plantarum de Estudos da Flora.

Martin P, Bateson P (2007). Measuring Behaviour: An Introductory Guide. Cambridge, Cambridge University Press.

Martins MM (2006). Comparative seed dispersal effectiveness of sympatric Alouatta guariba and Brachyteles arachnoides in southeastern Brazil. Biotropica 38: 57-63.

Michalski F, Peres CA (2007). Disturbance-mediated mammal abundance-area relationships in Amazonian forest fragments. Conservation Biology 21: 1626-1640.

Mori SA, Boom BM, de Carvalho AM, dos Santos TS (1983). Southern Bahian moist forests. Botanical Review 49: 155-232.

Moura ACD, McConkey KR (2007). The capuchin, the howler, and the caatinga: seed dispersal by monkeys in a threatened Brazilian forest. American Journal of Primatology 69: 220-226.

Muller-Landau HC (2007). Predicting the long-term effects of hunting on plant species composition and diversity in tropical forests. Biotropica 39: 372-384.

Nathan R, Muller-Landau HC (2000). Spatial patterns of seed dispersal, their determinants and consequences for recruitment. Trends in Ecology and Evolution 15: 278-285.

Peres CA (2000). Identifying keystone plant resources in tropical forests: the case of gum from Parkia pods. Journal of Tropical Ecology 16: 287-317.

Peres CA, Emilio T, Schietti J, Desmoulière SJ, Levi T (2016). Dispersal limitation induces long-term biomass collapse in overhunted Amazonian forests. Proceedings of the National Academy of Sciences of the United States of America 113: 892-897.

Ratiarison S, Forget PM (2011). Fruit availability, frugivore satiation and seed removal in 2 primate-dispersed tree species. Integrative Zoology 6: 178-194.

Schupp EW, Jordano P, Gómez J M (2010). Seed dispersal effectiveness revisited: a conceptual review. New Phytologist 188: 333-353.

Diet and Seed Dispersal by an Endangered Primate
Folia Primatol 2016;87:123-140 DOI: $10.1159 / 000447712$ 
Siemers BM (2000). Seasonal variation in food resource and forest strata use by brown capuchin monkeys (Cebus apella) in a disturbed forest fragment. Folia Primatologica 71: 181-184.

Stehmann JR, Forzza R, Salino A, Sobral M, Costa DP, Kamino LHY (2009). Plantas da Floresta Atlântica, vol 1. Rio de Janeiro, Jardim Botânico do Rio de Janeiro.

Tabarelli M, Peres CA (2002). Abiotic and vertebrate seed dispersal in the Brazilian Atlantic forest: implications for forest regeneration. Biological Conservation 106: 165-176.

Thomas WW, de Carvalho A, Amorim MA, Garrison J, Arbelaez AL (1998). Plant endemism in two forests in southern Bahia, Brazil. Biodiversity and Conservation 7: 311-322.

Tranbarger TJ, Dussert S, Joët T, Argout X, Summo M, Champion A, Morcillo F (2011). Regulatory mechanisms underlying oil palm fruit mesocarp maturation, ripening, and functional specialization in lipid and carotenoid metabolism. Plant Physiology 156: 564-584.

Valenta K, Fedigan LM (2010). Spatial patterns of seed dispersal by white-faced capuchins in Costa Rica: evaluating distant-dependent seed mortality. Biotropica 42: 223-228.

Vogel ER (2005). Rank differences in energy intake rates in white-faced capuchin monkeys, Cebus capucinus: the effects of contest competition. Behavioral Ecology and Sociobiology 58: 333-344.

Wenny DG, Levey DJ (1998). Directed seed dispersal by bellbirds in a tropical cloud forest. Proceedings of the National Academy of Sciences of the United States of America 95: 6204-6207.

Wehncke EV, Domínguez CA (2007). Seed dispersal ecology of non-restricted frugivores, capuchin monkeys in three Neotropical forests. Journal of Tropical Ecology 23: 519-528.

Wehncke EV, Hubbell SP, Foster RB, Dalling JW (2003). Seed dispersal patterns produced by white-faced monkeys: implications for the dispersal limitation of Neotropical tree species. Journal of Ecology 91: 677-685.

Zhang SY (1995). Activity and ranging patterns in relation to fruit utilization by brown capuchins (Cebus apella) in French Guiana. International Journal of Primatology 16: 489-507.

Zhang SY, Wang LX (1995). Fruit consumption and seed dispersal of Ziziphus cinnamomum (Rhamnaceae) by two sympatric primates (Cebus apella and Ateles paniscus) in French Guiana. Biotropica 27: 397-401. 